\title{
МЕТОДИЧЕСКИЕ ОСОБЕННОСТИ ФОРМИРОВАНИЯ ОБЩЕКУЛЬТУРНОЙ КОМПЕТЕНЦИИ КУРСАНТОВ МВД РОССИИ
}

\section{METHODICAL FEATURES OF FORMATION OF THE GENERAL CULTURAL COMPETENCE OF CURSORS OF THE RUSSIAN MIA}

M. Menshchikov

A. Zaviryukha V. Shalygin

Summary: The article discusses the methodological features of the formation of the general cultural competence of cadets of the Ministry of Internal Affairs of Russia. The author focuses on the fact that regarding the cadets of the Ministry of Internal Affairs, the study of this topic is not enough. The author comes to the conclusion that the formation of professional competence of a future employee of the Ministry of Internal Affairs should be carried out both on a personal and at a practical level, in an educational institution this should be reflected at the theoretical, methodological, and technological levels. The author defines the general cultural competence as an integrative quality of a person as a trajectory of the personal development of a future specialist of internal affairs bodies and is defined as the general level of education, the level of training, upbringing and development necessary to solve various life, training, and professional tasks. Based on the analysis of scientific and methodological sources, it is determined that the structure of general cultural competence in the process of studying all academic disciplines contains three components: cognitive, value-orientational, communicative-activity. The model for the formation of the general cultural competence of cadets of universities of the Ministry of Internal Affairs of Russia includes the presence of targeted, methodological, substantive, process and effective blocks, which will allow us to develop and create psychological and pedagogical conditions for the implementation of the model.

Keywords: general cultural competence, culture, integrative quality, personality, competence, knowledge.

\author{
Меньщиков Михаил Петрович \\ старший преподаватель, Омская академия \\ Министерства Внутренних Дел России \\ mih.mensh@yandex.ru \\ Завирюха Александр Михайлович \\ старший преподаватель, Омская академия \\ Министерства Внутренних Дел России \\ Шалыгин Вячеслав Геннадьевич \\ преподаватель, Омская академия Министерства \\ Внутренних Дел России
}

Аннотация: В статье рассматриваются методические особенности формирования общекультурной компетенции курсантов МВД России. Автор акцентирует внимание на том, что относительно курсантов МВД изучение данной темы недостаточно. Автор приходит к выводу, что формирование профессиональной компетентности будущего сотрудника МВД должно осуществляться как на личностном, так и на практическом уровне, в образовательном учреждении это должно быть отражено на теоретическом, методическом, технологическом уровнях. Автором общекультурная компетенция как интегративное качество личности определяется в качестве траектории личностного развития будущего специалиста органов внутренних дел и определяется как общий уровень образованности, уровень обученности, воспитанности и развития, необходимый для решения различных жизненных, учебных, профессиональных задач. На основе анализа научно-методических источников определено, что в структуре общекультурной компетенции в процессе изучения всех учебных дисциплин содержится три компонента: когнитивный, ценностно-ориентационный, коммуникативно-деятельностный. Модель формирования общекультурной компетенции курсантов ВУЗов МВД России включает наличие целевого, методического, содержательного, процессного и результативного блоков, что позволит разработать и создать психолого-педагогических условий для реализации модели.

Ключевые слова: : общекультурная компетенция, культура, интегративное качество, личность, компетенция, знания.

ных качеств и профессиональных компетенций.

В.Я. Кикоть изучал научно-методическое обеспечение для профессиональной подготовки курсантов МВД России [3, с. 102].

По мнению В.К. Савельева, важным фактором профессионального становления является гражданское воспитание курсантов МВД России [3, с.102].

В своей работе Л.Т. Бородавко рассматривал нормативно-правовые и методологические основы обучения и 
воспитания курсантов в образовательных учреждениях МВД России [3, с.102].

Исследования А.Г. Арсентьевой направлены на изучение проблемы нравственно-правовой культуры и процесса ее формирования у сотрудников ОВД [2, с.11].

Исследования Л.Г. Носковой и И.Ю. Фоменко направлены на изучение проблемы формирования профессиональной компетентности курсантов МВД России в целом [3, с.104].

В исследованиях А.Н. Завьяловой, А.И. Бобкова проводился анализ проблем и направлений становления личности курсантов в ВУЗах МВД России [2, с.12].

Согласно И.И. Ивановой, основополагающим фактором профессионального становления курсантов является сформированность их профессионального самосознания. В этой связи стоит отметить работу В.А. Тубальцевой, по мнению которой для формирования мотивации курсантов ВУЗов основным является проблемное обучение [2, с.10].

В работе Н.В. Пахаренко, И.Н. Зольниковой акцентируется внимание на том, что с учетом современных постоянно изменяющихся условий к образовательным организациям МВД России предъявляются требования в части уровня подготовки выпускников, связанной с уровнем сформированности целого ряда общих и профессиональных компетенций, отличающихся эффективностью и устойчивостью [6, с.302].

По мнению М.Н. Татамирова, успешность сотрудников МВД обусловлена эмоционально-волевой устойчивости, уровня сформированности умения принимать адекватные и оперативные решения в сложных служебных условиях, уровень сформированности управленческих компетенций для решения задач [2, с.11].

И.А. Акиндинова, Л.Ю. Баталова отмечали важность самоактуализации личности в различных сферах деятельности для формирования профессиональных компетенций [1, с.68]. Согласно М.П. Челомбицкой, интеллект и креативность следует рассматривать как факторы самоактуализации человека в инновационном обществе. В этой связи А.Ю. Василенко рассматривает личностное развитие в целом как один из факторов профессионального развития обучающегося [8, с.94]. Аналогичной позиции придерживается Е.В. Самаль, исследовавший развитие личности в процессе обучения в высшем учебном заведении [8, с.57].

В исследованиях П.Д. Никитенко рассматривался процесс профессиональной социализации курсантов военного ВУЗа и роль в ней самоактуализации личности курсанта [7, с.39].
По мнению С.А. Полякова, формирование профессиональной компетентности в целом представляет собой длительный процесс, растянутый во времени, и включает как систему личностных качеств, так и поведенческих характеристик. В этой связи целесообразно предположить, что формирование профессиональной компетентности будущего сотрудника МВД должно осуществляться как на личностном, так и на практическом уровне, в образовательном учреждении это должно быть отражено на теоретическом, методическом, технологическом уровнях [12].

Несмотря на то, что в научной литературе активно изучаются разные вопросы профессиональной подготовки курсантов ВУЗов МВД России, исследование общекультурной компетенции не встречается.

В исследованиях И.А. Зимней [5, с.35] и Т.В. Ежовой [4, с.16] рассматриваются общекультурная компетенция как интегративное качество личности обучающегося, позволяющая ему ориентироваться в социально-общественных и профессиональных отношениях. По мнению авторов, именно личностно-ориентированное обучение позволяет сформировать у обучающихся способность самостоятельно принимать решения и готовность брать на себя ответственность, ставить цели и достигать их.

С одной стороны, общекультурная компетенция не является профессионально обусловленной, то есть не зависит от сферы деятельности, с другой, - ее сформированность обеспечивает основу для формирования и развития профессиональных компетенций и их реализации [9, с.22]. В этой связи следует заключить, что несформированность или недостаточный уровень ее сформированность негативно влияет на личностный рост обучающегося, что отражается в целом на личностных и профессиональных результатах в образовательном процессе. Таким образом, общекультурная компетенция как интегративное качество личности определяет траекторию личностного развития будущего специалиста органов внутренних дел и определяется как общий уровень образованности, уровень обученности, воспитанности и развития, необходимый для решения различных жизненных, учебных, профессиональных задач.

Согласно О.А. Козлову, выпускник ВУЗа МВД должен обладать способностью определенные виды профессиональной деятельности: правоприменительной, правотворческой, экспертно-консультационной, правоохранительной, научно-исследовательской, организационно-управленческой и педагогической. В связи с этим, организация профессиональной подготовки должна соответствовать требованиям ООП к уровню сформированности не только профессиональных, но и общекультурных компетенций. Согласно позиции автора, общекультурная компетенция представляет собой 
совокупность знаний, направленных на развитие личности, логическое мышление, умение осуществлять поиск, обработку и систематизацию информации и обеспечивающая развитие профессиональной компетентности [6, c.302].

Проведенный анализ научно-методических источников позволяет предположить, что в структуре общекультурной компетенции в процессе изучения всех учебных дисциплин содержится три компонента:

- когнитивный: комплекс знаний, способность ориентироваться в источниках информации, способность к восприятию, анализу, синтезу, обобщению и классификации информации, речевая культура;

- ценностно-ориентационный: приобщение к культуре, духовным ценностям, передача ценностей [13, с.104];

- коммуникативно-деятельностный: поведенческие характеристики, отражающие способ обучения, присвоения культуры, способность решать познавательные задачи, понимать и объяснять явления действительности с позиции науки, способность ориентироваться в актуальных проблемах общественной жизни и обсуждать социально значимые проблемы, способность ориентироваться в мире социальных, нравственных и эстетических ценностей и соотносить их с определенной системой ценностей [10, с.21].

Каждый компонент имеет цели, задачи, содержание, критерии оценки и планируемые результаты. Соответственно, к методическим особенностям формирования общекультурной компетенции курсантов МВД следует отнести:

1. Сочетание системного, личностно-ориентированного и компетентностного подхода.

2. Реализация принципов системности, целостности, практикоориентированности, личностного опыта, направленности на самоактуализацию и развитие личностных качеств, необходимых для эффективного выполнения учебной и профессиональной деятельности.

3. Выделение целевого, методического, содержательного, процессного, результативного блоков.

4. Целевой блок направлен на определение целей и задач. Основная цель - формирование способ- ности осваивать культуру общества и реализовывать потенциал этой культуры в целях защиты и укрепления общественного порядка и национальной безопасности России [12, с.106].

5. Определение четких критериев:

а) отбора содержания (направленность содержания обучения на культуру деятельности, общения, мышления и речи, логическое мышление, ценностное отношения к современным процессам и перспективам развития Отечества, выработки гражданской позиции);

б) оценки (степень разнообразия используемых источников, наличие ценностных ориентиров в различных областях культуры, уровень сформированности навыков самостоятельной работы с историческими, культурными источниками, литературой и данными);

в) результативности обучения (высокий уровень развития мотивации к учебной деятельности, инициативности, познавательной активности в смежных областях и практической деятельности, высокий уровень развития ценностных ориентаций, ориентированных к общекультурным, эстетическим ценностям, представляющих, в целом, культуру личности, высокий уровень развития культуры речи.

6. Использование практических, проблемных, исследовательских методов, метода проектов, моделирования ситуаций, кейсов [11, с.16].

7. Формы организации: мини-лекции, дискуссии, проекты, групповая и командная работа, деловые игры, тренинги и практикум, психолого-педагогическая поддержка.

8. Средства обучения: Интернет-технологии, аудиои видеофайлы.

Таким образом, тщательная проработка целевого, методического, содержательного, процессного и результативного блоков позволит разработать модель формирования общекультурной компетенции курсантов ВУЗов МВД России и создать психолого-педагогических условий для реализации модели. Эффективность реализации каждого блока зависит от уровня теоретической и методической подготовки преподавателей к формированию общекультурной компетенции, а также научно-методического обеспечения учебного процесса ВУЗа.

\section{ЛИТЕРАТУРА}

1. Баталова, Л.Ю. Самоактуализация в профессиональной деятельности инженерно-технических работников: дис. ... канд. психол. наук / Л.Ю. Баталова. Москва, 2010. - 182 c.

2. Бронзино Л.Ю., Филатова М.Н. Компетентностный подход в образовании: проблема формирования общекультурных компетенций студентов в контексте социокультурной среды вуза / Л.Ю. Бронзино, М.Н. Филатова // Современные исследования социальных проблем. - 2012. - № 6 (14). - С. 10-12.

3. Гречухина Т.И. Формирование общекультурных компетенций у студентов университета: взаимосвязь процессов обучения и воспитания / Т.И. Гречухина // Известия Уральского федерального университета. Серия 1: Проблемы образования, науки и культуры. - 2012. - № 1. - С. 101 - 108. 
4. Ежова Т.В. Формирование общекультурной компетентности студентов в образовательном процессе вуза: автореф. дис. ... канд. пед. Наук / Т.В. Ежова. Оренбург, 2003.- 24 c.

5. Зимняя И.А. Ключевые компетенции — новая парадигма результата образования / И.А. Зимняя // Высшее образование сегодня. - 2003. - № 5. - С. 34-36.

6. К Козлов 0. А. Компетентность в профессиональной деятельности - результат профессиональной готовности / 0.А. Козлов // Электронное научно-практическое периодическое издание «Современные научные исследования и разработки». - 2017. - № 6(6). - С.302-303.

7. Никитенко, П.Д. Представление о мире и самоактуализации личности в процессе профессиональной социализации курсантов: дис. .... канд. психол. наук / П.Д. Никитенко. - Саратов, 2008. - 156 с.

8. Самаль, Е.В. Самоактуализация личности в процессе обучения в вузе: дис. .... канд. психол. наук / Е.В. Самаль. - Ярославль, 2008. - 245 с.

9. Троянская С.Л. Развитие общекультурной компетентности студентов средствами музейной педагогики: Автореф. дис. ... канд. пед. Наук / С.Л. Троянская. Ижевск, 2004. - 23 c.

10. Троянская С.Л. Общекультурная компетентность: опыт определения и структурирования / С.Л. Троянская // Культурно-историческая психология. - 2008. № 2. - C. 19-23.

11. Пахаренко Н.В., Зольникова И.Н. Модель определения уровня сформированности общекультурных и профессиональных компетенций / Н.В. Пахаренко, И.Н. Зольникова // Современные проблемы науки и образования. - 2012. - № 6. - С. 16-18.

12. Шадриков, В.Д. Формирование базовых компетенций на основе деятельностного подхода (на примере педагогической деятельности) / В.Д. Шадриков // Мир психологии. - 2014. - № 3. - С. 105-119.

13. Ярцев, В.В. Формирование ценностно-смысловых аспектов деятельности у курсантов вузов МВД России в процессе реализации личностноориентированнного обучения: атореф. дисс. канд. пед наук / В.В. Ярцев. - Владикавказ, 2014 - 27 с.

( ) Меньщиков Михаил Петрович (mih.mensh@yandex.ru), Завирюха Александр Михайлович , Шалыгин Вячеслав Геннадьевич.

Журнал «Современная наука: актуальные проблемы теории и практики»

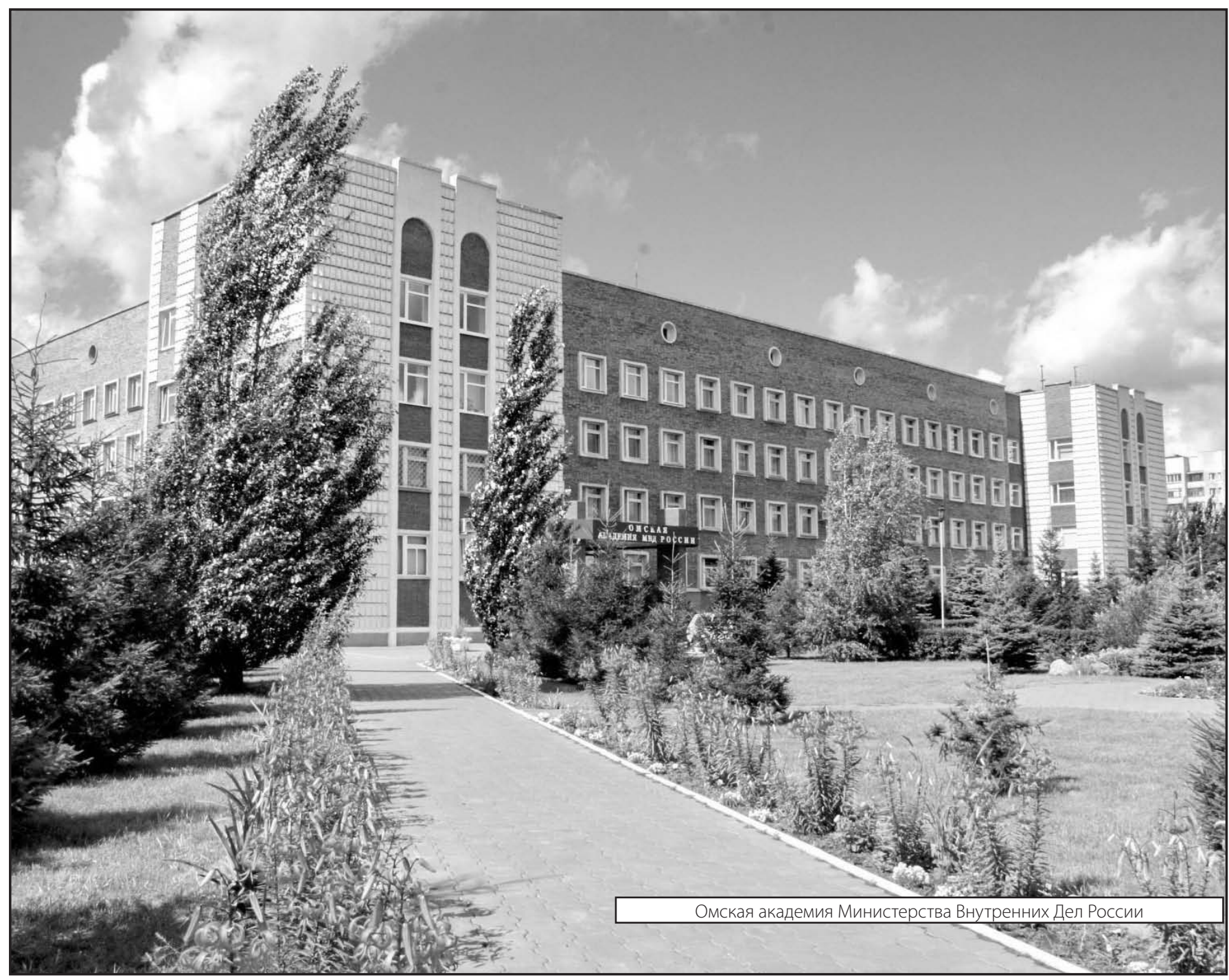

